\title{
"Transparency of the budget process as a prerequisite for financial decentralization in Ukraine"
}

\begin{tabular}{|c|c|c|}
\hline \multirow{5}{*}{ AUTHORS } & \multicolumn{2}{|c|}{ Inna Shkolnyk (D https://orcid.org/0000-0002-5359-0521 } \\
\hline & \multicolumn{2}{|c|}{ R http://www.researcherid.com/rid/l-7368-2018 } \\
\hline & \multirow{2}{*}{\multicolumn{2}{|c|}{$\begin{array}{l}\text { Tetyana Melnyk } \\
\text { Borys Mershchii (D) https://orcid.org/0000-0002-4831-6907 }\end{array}$}} \\
\hline & & \\
\hline & \multicolumn{2}{|c|}{$\mathbb{R}$ http://www.researcherid.com/rid/l-7627-2018 } \\
\hline ARTICLE INFO & \multicolumn{2}{|c|}{$\begin{array}{l}\text { Inna Shkolnyk, Tetyana Melnyk and Borys Mershchii (2018). Transparency of the } \\
\text { budget process as a prerequisite for financial decentralization in Ukraine. Public } \\
\text { and Municipal Finance, } 7(1), 12-20 \text {. doi:10.21511/pmf.07(1).2018.02 }\end{array}$} \\
\hline DOI & \multicolumn{2}{|c|}{ http://dx.doi.org/10.21511/pmf.07(1).2018.02 } \\
\hline RELEASED ON & \multicolumn{2}{|l|}{ Friday, 08 June 2018} \\
\hline RECEIVED ON & \multicolumn{2}{|l|}{ Wednesday, 02 May 2018} \\
\hline ACCEPTED ON & \multicolumn{2}{|l|}{ Friday, 25 May 2018} \\
\hline & \multicolumn{2}{|l|}{$(\mathrm{cc}) \mathrm{EY}$} \\
\hline LICENSE & \multicolumn{2}{|c|}{$\begin{array}{l}\text { This work is licensed under a Creative Commons Attribution } 4.0 \text { International } \\
\text { License }\end{array}$} \\
\hline JOURNAL & \multicolumn{2}{|l|}{ "Public and Municipal Finance" } \\
\hline ISSN PRINT & \multicolumn{2}{|l|}{$2222-1867$} \\
\hline ISSN ONLINE & \multicolumn{2}{|l|}{$2222-1875$} \\
\hline PUBLISHER & \multicolumn{2}{|c|}{ LLC "Consulting Publishing Company "Business Perspectives" } \\
\hline FOUNDER & \multicolumn{2}{|c|}{ LLC "Consulting Publishing Company "Business Perspectives" } \\
\hline$\sigma^{\circ}$ & 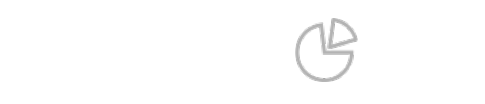 & ニ泣 \\
\hline NUMBER OF REFERENCES & NUMBER OF FIGURES & NUMBER OF TABLES \\
\hline 44 & 2 & 2 \\
\hline
\end{tabular}

(C) The author(s) 2022. This publication is an open access article. 


\title{
Inna Shkolnyk (Ukraine), Tetyana Melnyk (USA), Borys Mershchii (Ukraine) \\ Transparency of the budget process as a prerequisite for financial decentralization in Ukraine
}

\begin{abstract}
The introduction of a qualitatively new type of relationship between citizens and authorities, one in which every person would be guaranteed real observation and protection of the rights and freedoms in these bodies activity, should be one of the priority areas of socio-political transformation in Ukraine. The urgency of the improving local finances, the formation of local budgets and the use of their funds is increasing due to changes in local self-government.

The article proposes a scientific methodological approach to assessing the level of financial decentralization in Ukraine during the period of the decentralization reform (2014-2017). The universal integral indicator of financial decentralization has been calculated, which has found that local budgets improve public funds management, which is illustrated by the growth of the integral indicator level in dynamics.

A number of recommendations are also provided for improving the budget process transparency for each of the components: budget information openness, the state and effectiveness of budgetary supervision, and public participation in the budget process. The idea of the relationship between the budget process transparency and the results of the financial decentralization reform is proposed.
\end{abstract}

Keywords: financial decentralization, transparency of the budget process, local government, budgetary information openness, public participation in the budget process, public finance.

JEL Classification: E60, E63, P43.

Received on: $2^{\text {nd }}$ of May, 2018.

Accepted on: $25^{\text {th }}$ of May, 2018.

\section{Introduction}

Transparency of the budget process is one of the prerequisites that allows society to identify the problematic aspects of fiscal policy and interact with public authorities for their solution. The lack of a sufficient level of budget transparency threatens the key principles of civil society, which raises questions about the government actions effectiveness. Nowadays, the priorities of fiscal policy must be consistent with the public interests. The optimal financial decentralization of the budget, in turn, is a consequence of a balance between the interests of the state and the civil society. The problem of ensuring the socioeconomic needs of the entire population is especially relevant in today's period of change, when decentralization reform becomes one of the key aspects among the government strategic plans. Gradual fiscal reforms have taken place throughout the period of independence, but they were not systematic and, most importantly, did not include attributes of transparency. Transparency ideas in the budget process primarily include the components of the budgetary information openness, the adequate level

(C) Limited Liability Company "Consulting Publishing Company "Business Perspectives", 2018.

Inna Shkolnyk, Dr., Professor, Department of Finance, Banking and Insurance, Sumy State University, Ukraine

Tetyana Melnyk, Ph.D., Manager Data Systems and Fiscal Analysis, Revenue Estimating Division, Texas Comptroller of Public Accounts, USA

Borys Mershchii, Ph.D. Student, Department of Finance, Banking and Insurance, Institute for Business Technologies "Ukrainian Academy of Banking", Sumy State University, Ukraine. and effectiveness of budgetary supervision, and public participation in the budget process. Only if these conditions of transparency are met, the optimal level of fiscal decentralization can be achieved, which will mean the effectiveness of the government's reform.

The disproportions of regional development in Ukraine and the degree of budget funds centralization cause the growth of social tension in the society. In modern conditions, modernization of budget relations is an optimal tool for resolving social contradictions. The successful implementation of the financial decentralization reform, which aims to increase the significance of local budgets by providing them with a larger revenue base to address a wider range of local needs is a prerequisite for an increase in the level of socioeconomic development in Ukraine. However, substantial progress towards reform cannot be achieved without the basic needs of civil society in the context of free access to key budget documents, the possibility of participation in the budget process and control over the use of public funds and monitoring the results. Ensuring the fundamentals of the budget process transparency will confirm the democratic principles of Ukraine, adherence to the ideas of the European integration movement, and create a new system of relations between the public and the state.

\section{Literature review}

A number of scholars considered the issue of the effective functioning of local authorities. The 
problem of disproportions between the amount of funds available at the disposal of local selfgovernment bodies and the amount of expenditures to be exercised has always been particularly relevant. The scientific community has long been trying to determine the mechanisms of interaction between central authorities and local selfgovernment. Lindahl (1958), Herber (1979), Blankart (2000), Musgrave (2009) and others are among the scholars involved in the researching the problems of the local budgets formation.

Lindahl (1958) considered the distribution of the total value of collective goods between the two groups of taxpayers.

Herber (1979), Blankart (2000), and Musgrave (2009) investigated theoretical and practical aspects of determining the role of public spending in the country's economic growth.

Hryhorash, Korneyev, Leheza, Zolotukhina and Hryhorash (2018) investigated the relationship between the volume of sales in the small business and the revenues of local budgets in Ukraine.

According to Frolov, Pedchenko, and Vygovska (2017), the moratorium on land sales cancellation is one of the ways to solve the problem of local budgets filling.

In a context of scientific works related to some aspects of financial decentralization, the following scholars can be emphasized: Rondinelli, Nellis, and Cheema (1983), Conyers (1986), Anderson and Van Den Berg (1998), Rodden, Eskeland, and Litwack (2003), Arikan (2004), Bardhan and Mookherjee (2006), Bird (2006), Barankay and Lockwood (2007), Anderson and Baskaran (2011), Eyraud and Lusinyan (2011), Gemmell, Kneller, and Sanz (2013), Adam, Delis, and Kammas (2014), Lago Pengas, Fernandez-Leisagh, Vacero Garcia (2017), and others.

Ukrainian scientists also carry out research in the field of financial decentralization. Nyzhnyk (1997), Obolenskyi (2005), Martynenko (2001), Boryslavska (2012), Volokhova (2014), Bondaruk (2017) and others are among them.

Taking into account the specifics of the Ukrainian budgetary system, when forming a model for evaluating financial decentralization, the author's team relied heavily on the work of Ukrainian scholars. In particular, Bikadorova (2010) analyzed a system of indicators for assessing financial decentralization. Riabushka and Koilo (2013) used a model for assessing the financial capacity of local budgets. Uskov (2010) assesses the tax potential of territories in the context of reforming the public finance system. Sorokina (2011) proposed a methodology for determining the financial and fiscal sustainability of municipalities based on several groups of indicators: budgetary equilibrium, financial dependence, budget security and sustainability, budget resource efficiency. Based on the existing methodological work on the degree of financial decentralization, an author's approach to assessing the state of financial decentralization was proposed.

An important aspect of the study is the need to ensure the budget process transparency in the context of decentralization processes, which should become a prerequisite for the effective implementation of the reform.

It should be noted that many research groups engaged in the study of the budget process transparency, namely Benito and Bastida (1988), Tykhomyrova (2002), Heald (2003), Petrie (2003), de Renzio and Masud (2011), Demianiuk (2012), Radionova (2013), Wehner and de Renzio (2013), Bak (2014), Iholkina (2016), Vynnychenko (2017), Moloney and Stoycheva (2018), and others.

Considerable attention is paid to analyzing the budget openness index, which is calculated by International Budget Partnership and is considered one of the most universal methods for determining the degree of the budget process transparency. That is why most estimates of budget transparency were taken from the reports of this organization. Given the analysis of the problematic aspects of the budget process transparency, it would be appropriate to identify areas for improving the existing state of affairs.

Consequently, ensuring the basis for the budget process transparency is aimed at addressing the issue of budgetary information availability for the society. In addition to direct public awareness, it is necessary to create mechanisms for the real involvement of stakeholders in the budget process at all its stages. An important aspect is the control function of the public, which is to check the directions of using public funds and determine their effective use. That is, civil society is directly interested in raising the budget process transparency, as the results of the local authorities' activity directly affect the level of their lives. On the other hand, elective bodies of local self-government should be focused on maximally satisfying the community needs, which will potentially increase the population confidence.

\section{Methodology}

In order to study the state of financial decentralization in Ukraine, the method of constructing an integral indicator was chosen, which 
is considered the most appropriate taking the heterogeneity of the selected indicators into account. As a research object of the study, the budget system of Ukraine was selected at the level of the state budget and local budgets. The first stage of the evaluating financial decentralization was the selection of indicators that fully characterize the state of fiscal decentralization of the budget and some aspects of the budget process transparency. At the second stage, the selected indicators were differentiated into incentives and disincentives. The third stage involves the normalization of indicators. At the fourth stage, the integral indicator of the budget fiscal decentralization was calculated. The State Treasury Service of Ukraine, the Ministry of Finance of Ukraine, and the State Statistics Service made the information base for calculations. Figure 1 generalizes the received model of financial decentralization of the budget.

\section{Stage 1. Selection of indicators of the financial decentralization}

Share of local budget income in GDP; share of local budget expenditures in GDP; share of local budget income in consolidated budget of Ukraine (CBU) income; share of local budget expenditures in CBU expenditures; financial decentralization coefficient by consolidated budget expenditures; share of transfers in total income of local budgets; share of transfers in total expenditures of local budgets; ratio of transfers to local budgets from the state one, in \% to GDP; share of tax revenues in total income of local budgets; ratio of tax burden to GDP; share of non-tax revenues in total income of local budgets, etc.

Stage 2. Differentiation of indicators into incentives and disincentives

$\mathrm{a}_{\mathrm{ij}}^{\mathrm{s}}=\frac{\mathrm{x}_{\mathrm{ij}}}{\max \left\{\mathrm{x}_{\mathrm{ij}}\right\}} ; \mathrm{a}_{\mathrm{ij}}^{\mathrm{d}}=\frac{\min \left\{\mathrm{x}_{\mathrm{ij}}\right\}}{\mathrm{x}_{\mathrm{ij}}} \quad$\begin{tabular}{l}
$\begin{array}{l}\text { where } \mathrm{a}_{\mathrm{ij}}^{\mathrm{s}}, \mathrm{a}_{\mathrm{ij}}^{\mathrm{d}} \text { - normalized values of a range for incentives } \\
\text { and disincentives; } \\
\mathrm{x}_{\mathrm{ij}}-\text { current value of a range; } \\
\max \left\{\mathrm{x}_{\mathrm{ij}}\right\}-\text { maximum value of a range; } \\
\min \left\{\mathrm{x}_{\mathrm{ij}}\right\}-\text { minimum value of a range }\end{array}$ \\
\hline
\end{tabular}

Stage 4. Calculation of an integral indicator of financial decentralization

$$
\text { Dyi }=\sqrt[n]{a_{1 j}^{s / d} * a{ }_{2 j}^{s / d} * \ldots * a{ }_{n j}^{s / d}}
$$

where $D y i$ - integral indicator of financial decentralization; $\mathrm{a}_{1 \mathrm{j}}^{\mathrm{s} / \mathrm{d}} \ldots \mathrm{a}_{\mathrm{nj}}^{\mathrm{s} / \mathrm{d}}-$ normalized values of indicators; $n$ - number of indicators

Figure 1. Model for assessing the financial decentralization of a budgetary system

\section{Results}

According to the above methodology, indicators of financial decentralization were calculated. Table 1 presents the results of calculating the financial decentralization indicators.

As a result of the calculations, it has been established that the share of local budgets income in GDP is gradually increasing from 2014, indicating an increase in the role of local budgets and the transfer of more financial resources to them. In addition to financial resources, a larger number of budget authorities have been transferred to the local level, which is confirmed by an increase in the share of local budget expenditures in GDP. There is no unidirectional dynamics of the change in the share of local budget revenues in the consolidated budget revenues, since in 2015 there was a decrease in the researched indicator with further gradual growth in the coming years. It should be noted that the share of local budgets' expenditures in the consolidated budget of Ukraine significantly exceeds the above indicator of the share of revenues in the consolidated budget. This significant difference is a negative tendency, since this imbalance in sources of financing for the needs of socio-economic development can only be solved by means of transfer payments from the state budget. Despite this, the share of transfers in local budget revenues is gradually decreasing from 2015, which can partly be explained by providing local communities with a larger resource base to form their own income sources. However, given the share of transfers to local budgets in relation to GDP, the dynamics of 
improvement is not observed, since in 2017 this ratio was $9.3 \%$, which is the highest value for the period under study. The share of tax revenues from local budgets is growing to a certain degree, which is confirmed by an increase in the tax burden relative to GDP. One of the indicators of the budget process transparency is the rate of the plan implementation for income and expenditures of local budgets. The $100 \%$ execution of the approved budget is the most optimal, as it confirms the budget forecast stability. In Ukraine, there was a certain overfulfilment of the plan for local budget revenues in 2015-2017, while the level of the expenditure plan implementation in any of the preceding years did not exceed $93 \%$, indicating some problems in budget planning. The coefficient of autonomy for the local budget revenues confirms a slight increase in the number of own sources of local budget revenues. There was no significant increase in real tax potential for the investigated period.

Table 1. Indicators of financial decentralization in Ukraine for 2014-2017

\begin{tabular}{|c|l|c|c|c|c|}
\hline \multirow{2}{*}{ No. Indicator } & \multicolumn{4}{|c|}{ Year } \\
\cline { 3 - 6 } & & 2014 & 2015 & 2016 & 2017 \\
\hline 1 & Share of local budgets income in GDP, $\%$ & 14.783 & 14.876 & 15.365 & 16.838 \\
\hline 2 & Share of local budget expenditures in GDP, \% & 14.404 & 14.153 & 14.709 & 16.636 \\
\hline 3 & Share of local budgets income in CBU income, \% & 22.154 & 18.482 & 21.810 & 22.567 \\
\hline 4 & Share of local budget expenditures in CBU expenses, \% & 42.733 & 40.737 & 41.936 & 46.370 \\
\hline 5 & Financial decentralization coefficient by consolidated budget expenditures & 0.490 & 0.425 & 0.448 & 0.482 \\
\hline 6 & Share of transfers in local budgets income, \% & 56.390 & 58.798 & 53.366 & 54.293 \\
\hline 7 & Share of transfers in local budget expenditures, \% & 0.965 & 1.123 & 4.491 & 1.203 \\
\hline 8 & Ratio of transfers to local budgets from the state one, in \% to GDP & 8.475 & 8.906 & 8.860 & 9.342 \\
\hline 9 & Share of tax revenues in total income of local budgets, \% & 37.709 & 33.362 & 40.121 & 40.033 \\
\hline 10 & Tax burden to GDP ratio, \% & 23.458 & 25.651 & 27.309 & 27.772 \\
\hline 11 & Share of non-tax revenues in total income of local budgets, \% & 5.292 & 6.843 & 5.970 & 5.173 \\
\hline 12 & Level of plan fulfillment for local budgets income, \% & 91.5 & 103.5 & 104.2 & 100.7 \\
\hline 13 & Level of plan fulfillment for local budget expenditures, \% & 84.545 & 93.859 & 93.189 & 92.823 \\
\hline 14 & Coefficient of income autonomy & 0.436 & 0.409 & 0.466 & 0.457 \\
\hline 15 & Autonomy coefficient for local budget expenditures & 0.448 & 0.430 & 0.487 & 0.463 \\
\hline 16 & Tax potential coefficient & 0.238 & 0.193 & 0.226 & 0.243 \\
\hline 17 & Tax efforts coefficient for local bodies & 0.222 & 0.185 & 0.218 & 0.226 \\
\hline
\end{tabular}

After the distribution of the indicators into incentives and disincentives, the indicators were normalized. The next step was to determine the integral result of assessing the financial decentralization in Ukraine (see Figure 2).

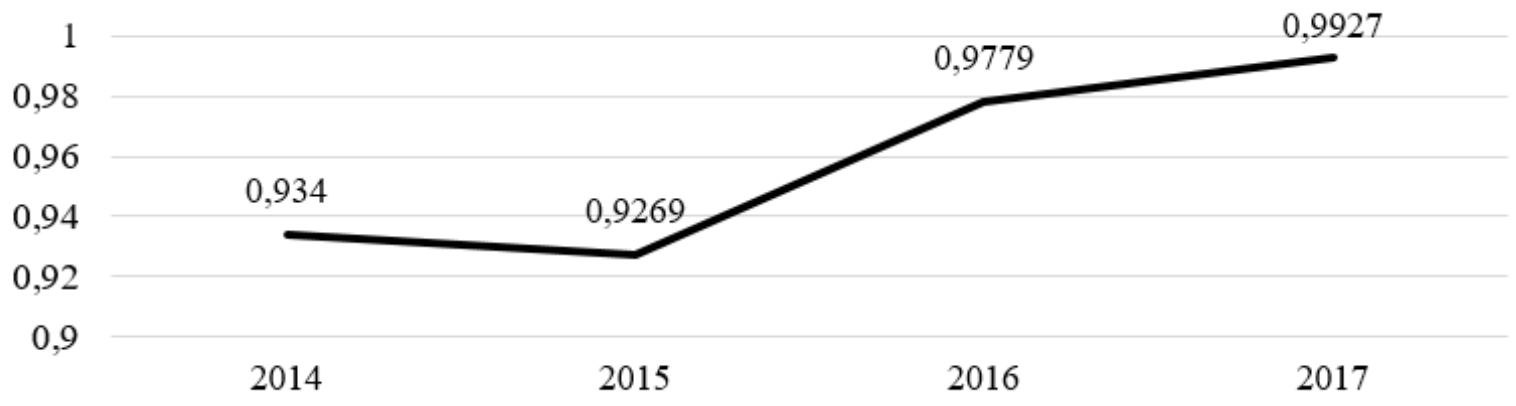

Figure 2. Integral indicator of financial decentralization in Ukraine

The obtained results indicate that intergovernmental transfers are a significant factor influencing the level of financial decentralization of local budgets, which confirms the correctness of the chosen course for decentralization processes. Financial decentralization reached the highest level in 2017, which means the correctness of the course chosen. Among the reasons for this result are the gradual increase in the share of local budget expenditures in the expenditures of the consolidated budget of Ukraine (CBU) and in GDP, the share of local budget revenues in GDP, and a sufficient level of incomes autonomy. That 
is, the period from 2014 should be characterized as a period of financial decentralization reform. The results indicate an increase in the integral indicator of financial decentralization year by year.

The analysis of the budget environment transparency as a prerequisite for financial decentralization is an important aspect of the existing reform. Citizens should receive sufficient budgetary information, participate in the budget process, which will lead to more complete satisfaction of the socio-economic development needs.

The ideas of the budget process transparency are disseminated by key international organizations: the IMF and the World Bank. The most comprehensive study of the level of the budget process transparency is conducted by the International Budget Partnership (IBP) since 2006. Nowadays, the 2017 report is the sixth already published research paper on this subject. The latest report examines the state of budget transparency in 115 countries around the world based on 145 points. The evaluation is carried out by independent experts on the basis of a clearly defined methodology.

Taking into account Ukraine's Euro-integration trends, one can propose comparing the state of the Ukrainian budget system transparency with similar indicators of the Eastern European countries that are already the EU members.

Table 2. Assessment of budget transparency of Eastern European countries for 2017

\begin{tabular}{|l|c|c|c|}
\hline \multicolumn{1}{|c|}{ Country } & Budgetary information openness & $\begin{array}{c}\text { State and efficiency } \\
\text { of the supervision }\end{array}$ & Level of public participation \\
\hline Romania & 75 & 63 & 11 \\
\hline Slovenia & 69 & 80 & 22 \\
\hline Bulgaria & 66 & 59 & 9 \\
\hline Czech Republic & 61 & 82 & 24 \\
\hline Poland & 59 & 82 & 9 \\
\hline Slovakia & 59 & 56 & 7 \\
\hline Moldova & 58 & 59 & 26 \\
\hline Croatia & 57 & 59 & 30 \\
\hline Ukraine & 54 & 83 & 11 \\
\hline Hungary & 46 & 65 & 2 \\
\hline Serbia & 43 & 63 & \\
\hline
\end{tabular}

Source: Compiled by the authors based on IBP data.

As a result of the budget transparency comparison, it was found that Ukraine is on the 9th place out of 11 Eastern European countries studied that are the EU members. If we take into account the global rating of countries in terms of budgetary information openness, then Ukraine occupies 41st position. A detailed consideration of the key component of budget transparency has highlighted that the level of budgetary information openness in Ukraine by 21 points lags behind the key player of the region - Romania. Estimation of the budgetary information openness of Ukraine is 54 points out of 100 possible, which corresponds to the limited availability of information to the public. As a comparison, the world average is 42 points, while in Eastern Europe it is 59 points. The score obtained by Ukraine is the result of an assessing the availability and timeliness of the publication of eight key budget documents: the preliminary budget comment (budget resolution), the draft budget, the law on the state budget, interim budget reports, the semiannual budget report, the budget performance report, the audit report and civil budget. The study indicates that Ukraine did not publish only a semiannual budget report from this list, which usually contains information on the implementation of the budget by the middle of the fiscal year and an adjusted budget projection at the end of the year. In addition to the availability and timeliness of publishing budget records, the completeness of the information provided for each of the submitted documents was assessed. As a result, the state budget law (95 points), interim budget reports (93 points) and the audit report (86 points) were the highest. The budget draft (48 points), the budget resolution (45 points) and the public budget of Ukraine (42 points) are estimated at the limited level of completeness and effectiveness of the information. That is, budgetary information openness in Ukraine does not reach global criteria, but the filling of key budget documents received a positive evaluation. 
More attention should be paid to the problematic aspects that need to be improved in accordance with the International Budget Partnership assessment. For example, the draft state budget presents forecast data for at least two periods ahead of budget expenditures only in terms of functional classification and partly in economic terms. The highest scores were received from countries providing publicly-projected information on future state budget expenditures in three classifications: functional, economic, and administrative. Particularly, experts note the need to improve the forecast of budget expenditures, taking into account the high level of external debt of Ukraine.

It is also noted that in the draft budget, more attention should be paid to the detailed prediction of budget revenue sources for at least two budget periods ahead. The experts estimated that the forecasted information provided comprised twothirds of revenue-generating budget sources. Preliminary data are provided for key tax sources, but non-tax revenues require more attention. Attention is also being paid to the openness of information regarding the debt burden of the country, in particular on the key foreign and domestic creditors of the country, and interest rates. An analysis of budgetary sensitivity was characterized by a negative assessment that should allow for possible changes in the budgetary situation in the context of the key macroeconomic indicators effect, in particular inflation index, changes in the real GDP value, etc. For Ukraine, these proposals for the analysis of budget sensitivity are particularly relevant, taking into account raw material dependence on energy resources, an unstable political component and other destructive factors. Among the disadvantages of the budget execution report, one can distinguish the lack of comparison of forecast macroeconomic indicators at the beginning of the year with the results after the end of the budget period.

The impact of new reforms in various areas of public life on the level of budget income and expenditures was assessed at 33 points out of 100 . This can be explained by the fact that the implementation of important reforms (educational, medical) is carried out with insufficient consideration of all factors that will affect the state of the budget system in the process of their implementation. In developed countries, each complex of reforms is presented to the public in a detailed format, including the budget component.

There is no open information on forecasting longterm budgetary prospects (more than 10 years), taking into account various scenarios of development: demographic situation, macroeconomic estimates, and different risks. Consolidated information on charitable assistance provided to Ukraine is limited. It is revealed that an aspect regarding the information disclosure on financial and nonfinancial assets belonging to state authorities, namely their number, state, market value, requires considerable attention.

Provision of information on extrabudgetary funds in Ukraine requires to be more detailed as it will provide an understanding of the real financial situation in the country. In Ukrainian realities, the public should receive reliable data on the situation of the Pension Fund of Ukraine, social insurance funds. Given the dependence on energy exports, in fact, information regarding the financial status of Naftohaz of Ukraine should be classified as a category of extrabudgetary funds. In particular, the budget documents do not provide publicly available information on state transfers to Naftohaz of Ukraine. The lack of this information in open access potentially causes the risks of concealment and manipulation of budget indicators.

One of the ways to improve the classification of expenditures in Ukraine, taking international democratic aspirations into account, should be to develop its own demographic, gender, and regional cost allocation concepts. Given the importance of the agrarian component of the budget, it is possible to form a certain kind of agrarian budgeting, taking into account the geographical component. For example, the budgeting experience in India takes into account the aspects of society stratification. The UN supports gender budgeting to ensure gender equality

Also, a higher assessment of the budgetary information openness requires the provision of more detailed information on the debt category (internal or external), the total amount of external debt, the structure of debt instruments and the size of interest rates on them.

Despite Ukraine's lagging behind its neighbors on the level of budgetary information openness, there are positive aspects. By the state and effectiveness of supervision and the level of public participation in the budget process, Ukraine ranks first among the selected group of countries. But despite this, according to the International Budget Partnership estimates, the public is given little opportunity to participate in the budget process. By the level of public participation in the budget process, Ukraine received a score of 30 , which means a minimum level. At the same time, Romania, which is the leader in the region, provides the public with insignificant opportunities for participation in the budget process, as evidenced by six points. 
The efficiency and supervision of the budget process in Ukraine is estimated 83 points, which is a sufficient level. Within the group of investigated countries, the work in budgetary supervision of Ukraine was rated at the highest point. Ukraine has received high estimates for budgetary supervision both in the process of drafting and approving the budget, and in the process of its implementation. One of the new aspects of budgetary supervision that has begun to emerge in developed democratic countries is the activity of independent supervisory institutions, the main purpose of which is to increase confidence in public finances by checking the adequacy of budget projections and independent verification of government actions. Independent financial institutions may have various organizational forms, such as parliamentary budget services or fiscal councils. But there is currently no such supervisory institution in Ukraine. Some countries in Eastern Europe already have an experience of the functioning of such supervisory bodies, namely Romania, Slovakia, Bulgaria, Croatia, Hungary, and Serbia. That is, the already existing high level of budgetary supervision in Ukraine can be increased by adopting positive trends that are in neighboring countries that have already implemented these institutions in the budget process.

While considering Ukraine's estimates in the previous report for 2015, then improvements have been made in all areas of budget transparency. So the level of budgetary information openness has increased from 46 points in 2015 to 54 in 2017. Similar positive developments have also taken place in fiscal supervision: the score has increased from 79 points in 2015 to 83 in 2017. The public involvement in the budget process has also improved, since the score from 23 points in 2015 has increased to 30 points in 2017 . Undoubtedly, benchmarking is not necessary for 2015 and 2017, as there are differences in key issues that are changing and expanding. In particular, the 2017 report has considerably revised the methodology for assessing public participation through the emergence of new international principles for a global initiative on transparency in the tax and financial area. But the general trend of change as well as the overall level of assessing each component of budget transparency can be analyzed. The comparison shows a positive trend towards improving the level of budget transparency in Ukraine. However, there are a number of points that need to be addressed in order to achieve a higher degree of transparency in the budget process, which in turn will allow for a more effective reform of financial decentralization.

\section{Conclusion}

Thus, in the course of the research, a scientific methodological approach to assessing the state of financial decentralization is proposed. The approach is based on the ease of the index method use. Among the advantages of the method chosen, the use of indicators of incentives and disincentives, and the indicators normalization should be noted. It was established that the chosen course for the implementation of the financial decentralization reform is reflected in the real indicators of evaluation. It should be noted that the integral indicator reached its highest level in 2017, which is explained by an increase in the share of local budgets in GDP, a decrease in the transfer dependence on local budgets, an increase in the share of tax revenue in the budget, and the growth of autonomy in income. That is, there are positive changes in the direction of increasing the autonomy of local budgets.

However, decentralization reform would have had less positive effect without proper ground. The basis of the developed system of local finances should be a satisfactory level of the budget process transparency. The study compared the budget process transparency in Ukraine and the countries of Eastern Europe that are EU members. It is found that Ukraine ranks 9th out of 11 countries of Eastern Europe that are members of the EU and occupies 41 st position in the global ranking of the budget process transparency. It has been established that the budget documents openness in Ukraine is limited, which is primarily due to the lack of publication of a half-yearly budget report. Considerable attention should be paid to forecasting sources of revenue and budget expenditures, which will improve the filling of already existing documents. It is also recommended to pay more attention to the analysis of budget sensitivity, both from macroeconomic indicators (inflation rate, exchange rate changes), and from external economic (rising energy prices) and domestic (implementation of educational, medical reform) factors. Disclosure of information on the extrabudgetary funds, in particular the pension fund, will significantly improve the transparency. Data list on external debt in the context of the debt instruments structure, interest rates, owners of debt instruments needs to be expanded. The effective supervision over the budget process is an important component of transparency. Among the International Budget Partnership recommendations in this area, the need to establish independent supervisory institutions should be noted, the main objective of which is to increase confidence in public finances by checking the budget forecasts adequacy and independent verification of state authorities' actions. It is undoubtedly worth 
noting the public participation in the budget process, since the assessment from 23 points in 2015 has increased to 30 points in 2017, indicating an increase in the level of public involvement in some stages of the budget process.

It has been established that the financial decentralization reforming should be inextricably connected with the increase in the level of the budget process transparency, since the synergistic effect of these two aspects combination will lead to a real increase in the level of satisfying the needs of citizens.

\section{Acknowledgement}

The study was undertaken as part of state-financed research "Shaping a system of ensuring the public finance transparency as a prerequisite for fight against corruption in Ukraine" (state registration number 0118U003585).

\section{References}

1. Adam, A., Delis, M., \& Kammas, P. (2014). Fiscal Decentralization and Public Sector Efficiency. Economics of Governance, 15, 17-49.

2. Anderson, J. E., \& Van Den Berg, H. (1998). Fiscal Decentralization and Government Size: An International Test for Leviathan Accounting for Unmeasured Economic Activity. International Tax and Public Finance, 5(2), 171186.

3. Arikan, G. (2004). Fiscal Decentralization: A Remedy for Corruption? International Tax and Public Finance, 11, $175-195$

4. Bak, N. А. (2014). Прозорість бюджетного процесу як фактор підвищення ефективності бюджетного менеджменту в Україні [Prozorist biudzhetnoho protsesu yak factor pidvyshchennia efektyvnosti biudzhetnoho menedzhmentu v Ukraini]. Ekonomika: realii chasu, 1(11), 43-49. Retrieved from http://economics.opu.ua/files/archive/2014/n1.html

5. Barankay, I., \& Lockwood, B. (2007). Decentralization and the Productive Efficiency of Government: Evidence from Swiss Cantons. Journal of Public Economics, 91, 1197-1218.

6. Bardhan, P., \& Mookherjee, D. (2006). Decentralisation and Accountability in Infrastructure Delivery in Developing Countries. The Economic Journal, 116(508), 101-127.

7. Baskaran, T. (2011). Fiscal Decentralization, Ideology, and the Size of the Public Sector. European Journal of Political Economy, 27(3), 485-506.

8. Benito, B., \& Bastida, F. (1988). Budget Transparency, Fiscal Performance, and Political Turnout: An International Approach. Public Administration Review, 69(3), 403-417.

9. Bikadorova, N. O. (2010). Фінансова децентралізація місцевого самоврядування [Finansova detsentralizatsiia mistsevoho samovriaduvannia]. Ekonomichnyi visnyk Donbasu, 2, 145-150.

10. Bird, R., \& Ebel, R. (2006). Fiscal federalism and national unity. In E. Ahmad \& G. Brosio (Eds.), Handbook of Fiscal Federalism (pp. 499-521). Cheltenham: Edward Elgar.

11. Blankart, Sh. (2000). Державні фінанси в умовах демократії [Derzhavni finansu v umovakh demokratii]. Trans. from German. In V. M. Fedosov (656 p.). Kyiv: Lybid.

12. Bondaruk, T. G., \& Bondaruk, I. S. (2017). State regulation of financial support of municipal authority under decentralization conditions. Naukovyi visnyk Polissia, 4(12), 1, 16-21.

13. Boryslavska, O. M. et al. (2012). Децентралізаиія публічної влади: досвід європейських країн та перспективи України [Detsentralizatsiia publichnoi vlady: dosvid yevropeiskykh krain ta perspektyvy Ukrainy] (128 p.). Kyiv: Sophia LLC.

14. Conyers, D. (1986). Decentralisation and Development: A Framework for Analysis. Community Development Journal, 21(2), 88-100.

15. De Renzio, \& P. Masud, H. (2011). Measuring and Promoting Budget Transparency: The Open Budget Index as a Research and Advocacy Tool. Governance, 24(3), 607-616.

16. Demianiuk, A. V. (2012). Проблеми та перспективи забезпечення прозорості бюджетного процесу на субнаціональному рівні [Problemy ta perspektyvy zabezpechennia prozorosti biudzhetnoho protsesu na subnatsionalnomu rivni]. Nauka i ekonomika, 1(25), 30-37.

17. Eyraud, L., \& Lusinyan, L. (2011). Decentralizing spending more than revenue: Does it hurt fiscal performance? (IMF Working Paper 11/226).

18. Frolov, S., Pedchenko, N., \& Vygovska, N. (2017). Financial mechanism of state land regulation in Ukraine. Accounting and Financial Control, 1(1), 15-22. https://doi.org/10.25161/afc.1(1).2017.02

19. Gemmell, N., Kneller, R., \& Sanz, I. (2013). Fiscal decentralization and economic growth: Spending versus revenue decentralization. Economic Inquiry, 51, 1915-1931.

20. Heald, D. (2003). Fiscal Transparency: Concepts, Measurement and UK Practice. Public Administration, 81(4), 723-759.

21. Herber, B. P. (1979). Modern Public Finance. Illinois: Richard D. Irwin INC.

22. Hryhorash, O., Korneyev, M., Leheza, Ye., Zolotukhina, L., \& Hryhorash, T. (2018). The development of small business as a source of formation of local budget revenues in Ukraine. Investment Management and Financial Innovations, 15(1), 132-140. https://doi.org/10.21511/imfi.15(1).2018.12

23. Iholkin, I. V. (2016). Роль транспарентності бюджетних відносин у системі управління державними 
фінансами [Rol transparentnosti biudzhetnykh vidnosyn u systemi upravlinnia derzhavnymy finansamy]. Naukovi pratsi, 1(74), 50-67.

24. International Budget Partnership (2017). Retrieved from https://www.internationalbudget.org.

25. Lindahl, E. (1958). Just Taxation - A Positive Solution. In R. A. Musgrave \& A. T. Peacock (Eds.). Classics in the Theory of Public Finance. International Economic Association Series. London: Palgrave Macmillan.

26. Malicka, L. (2017). Impact of Fiscal Decentralization on Local Indebtedness in the EU Countries. Current Trends in Public Sector Research, 163-169.

27. Martynenko, P. F. (2001). Децентралізація у здійсненні державної влади як конституційний принцип в Україні [Detsentralizatsiia u zdiisnenni derzhavnoi vlady yak konstytutsiinyi pryntsyp v Ukraini]. Ukrainskoyevropeiskyi zhurnal mizhnarodnoho ta porivnialnoho prava, 1(2), 23.

28. Musgrave, R. A., \& Musgrave, P. B. (2009). Государственные финансы: теория и практика [Gosudarstvenniye finansy: teoriya i praktika] (715 p.). In T. G. Nesterenko et al.; Translated from English by Krutikov, D. V. and Sidorov, A. V. Moscow: Biznes Atlas.

29. Moloney, K., \& Stoycheva, R. (2018). Partial Two-Way Mirror: International Organization Budget Transparency. Global Policy, 9(1).

30. Nyzhnyk, N. P. (Ed.) et al. (1997). Державне управління в Україні: цеентралізація і децеентралізація [Derzhavne upravlinnia $v$ Ukraini: tsentralizatsiia $i$ detsentralizatsiia] (448 p.). Kyiv: UADU pry Prezydentovi Ukrainy.

31. Obolenskyi, O. Yu. (2005). Державне управління та державна служба [Derzhavne ирravlinnia ta derzhavna sluzhba] (480 p.). Kyiv: KNEU.

32. Petrie, M. (2003). Promoting Fiscal Transparency: The Complementary Roles of the IMF, Financial Markets, and Civil Society (Working Paper 03/199). Washington DC: International Monetary Fund.

33. Radionov, Yu. D. (2013). Прозорість бюджетної системи - гарантія їі ефективності [Prozorist biudzhetnoi systemy - harantiia yii efektyvnosti]. Investytsii: praktyka ta dosvid, 14, 14-21.

34. Riabushka, L. B., \& Koilo, V. V. (2013). Аналітична оцінка фінансової спроможності місцевих бюджетів у забезпеченні соціально-економічного розвитку регіонів [Analitychna otsinka finansovoi spromozhnosti mistsevykh biudzhetiv u zabezpechenni sotsialno-ekonomichnoho rozvytku rehioniv]. Biznes Inform, 11, $148-155$.

35. Rodden, J., Eskeland, G., \& Litwack, J. (2003). Fiscal Decentralization and the Challenge of Hard Budget Constraints. Cambridge MA: Massachusetts Institute of Technology Press.

36. Rondinelli, D., Nellis, J., \& Cheema, G. (1983). Decentralization in developing countries. Washington, D.C., U.S.A.: World Bank.

37. Santiago, Lago-Peñas, Xoaquín, Fernández-Leiceaga, Alberto, \& Vaquero-García (2017). Spanish fiscal decentralization: A successful (but still unfinished) process. Environment and Planning c-Politics and Space, 35(8), 1509-1525.

38. Sorokina, T. V. (2011). Оценка финансово-бюджетной устойчивости муниципальных образований [Оtsenka finansovo-biudzhetnoy ustychivosti munitsipalnykh obrazovaniy]. Izvestiya Irkutskoy gosudarstvennoy ekonomicheskoy akademii (BGUEP), 5, 35-40.

39. Stratan, A., \& Manole, T. (2017). Program and performance based budgeting - way towards consolidating local financial autonomy. Management Theory and Studies for Rural Business and Infrastructure Development, 39(4), 490-509.

40. Тykhomyrova, Ye. В. (2002). Транспарентність і відкритість діяльності влади та шляхи їх забезпечення в Україні [Transparentnist $i$ vidkrytist diialnosti vlady ta shliakhy yii zabezpechennia v Ukraini] (pp. 39-43). Kyiv: KM Akademiia. Retrieved from http://www.library.ukma.kiev.ua/elib/NZ/NZV20_2002polityk/08tyhomyrova. eb.pdf

41. Uskov, I. (2010). Оценка налогового потенциала территорий в условиях реформирования местных финансов [Otsenka nalogovogo potentsiala territoriy v usloviyakh reformirovaniya mestnykh finansov]. Finansy, banky, investytsii: Naukovyi visnyk, 3, 16-24.

42. Volokhova, I. S. (2014). Місцеві фінанси та перспективи поглиблення фінансової децентралізації в Україні [Mistsevi finansy ta perspektyvy pohlyblennia finansovoi detsentralizatsii v Ukraini] (462 p.). Odesa: Atlant.

43. Vynnychenko, N. V. (2017). Проблеми забезпечення транспарентності бюджетного процесу в Україні [Problemy zabezpechennia transparentnosti biudzhetnoho protsesu v Ukraini]. Biznes-navihator, 3(42), $127-133$. Retrieved from http://business-navigator.ks.ua/journals/2017/42_2017/28.pdf

44. Wehner, J., \& de Renzio, P. (2013). Citizens, Legislators, and Executive Disclosure: The Political Determinants of Fiscal Transparency. World Development, 41(1), 96-108. 